\title{
Episodic runoff generation at Central European headwater catchments studied using water isotope concentration signals
}

\author{
Jana Votrubova ${ }^{1 *}$, Michal Dohnal ${ }^{1}$, Tomas Vogel ${ }^{1}$, Martin Sanda ${ }^{1}$, Miroslav Tesar ${ }^{2}$ \\ ${ }^{1}$ Faculty of Civil Engineering, Czech Technical University in Prague, Thákurova 7, 16629 Prague 6, Czech Republic. \\ 2 Institute of Hydrodynamics of the Czech Academy of Sciences, Pod Pat'ankou 5, Prague 6, Czech Republic. \\ * Corresponding author. Tel.: +420 22435 4355. E-mail: jana.votrubova@fsv.cvut.cz
}

\begin{abstract}
Hydrological monitoring in small headwater catchments provides the basis for examining complex interrelating hydraulic processes that govern the runoff generation. Contributions of different subsurface runoff mechanisms to the catchment discharge formation at two small forested headwater catchments are studied with the help of their natural isotopic signatures. The Uhlirska catchment (Jizera Mts., Czech Republic) is situated in headwater area of the Lusatian Neisse River. The catchment includes wetlands at the valley bottom developed over deluviofluvial granitic sediments surrounded by gentle hillslopes with shallow soils underlain by weathered granite. The Liz catchment (Bohemian Forest, Czech Republic) is situated in headwater area of the Otava River. It belongs to hillslope-type catchments with narrow riparian zones. The soil at Liz is developed on biotite paragneiss bedrock. The basic comparison of hydrological time series reveals that the event-related stream discharge variations at the Uhlirska catchment are bigger and significantly more frequent than at Liz. The analysis of isotope concentration data revealed different behavior of the two catchments during the major rainfall-runoff events. At Uhlirska, the percentage of the direct runoff formed by the event water reaches its maximum on the falling limb of the hydrograph. At Liz, the event water related fraction of the direct outflow is maximal on the rising limb of the hydrograph and then lowers. The hydraulic functioning of the Uhlirska catchment is determined by communication between hillslope and riparian zone compartments.
\end{abstract}

Keywords: ${ }^{18} \mathrm{O}$ isotope; Headwater catchment runoff; Subsurface runoff; Tracer; Rainfall-runoff episodes.

\section{INTRODUCTION}

The rainfall-runoff dynamics and runoff generation processes represent an area of research with continuous development (e.g., Lamacova et al., 2014; Wenninger et al., 2008). Progress in the use of environmental tracers in hydrology significantly enhanced understanding of hydrological processes at hillslope and catchment scale. Specifically, studies based on isotopic (stable water isotopes, e.g., Dincer et al., 1970) and geochemical (major cations and anions, e.g., Pinder and Jones, 1969) tracers revealed a substantial role of the subsurface flow contribution to runoff events, which partly contradicted the traditional concept of the runoff formation. Typically, groundwater mixing and residence times are studied by isotopic tracers (e.g., Maloszewski and Zuber, 1996; McGuire and McDonnell, 2006). Recently, concurrent use of isotopic and geochemical tracers has been found helpful in identification of subsurface mixing mechanisms (e.g., Glynn and Plummer, 2005; Kirchner et al., 2010). In temperate boreal headwater catchments, the mixing was found to take place mostly in riparian zones (Burns et al., 2003), including wetlands (Kurtz et al., 2007). McGlynn et al. (2003) studied riparian and hillslope zone contributions, they concluded that riparian water dominated between events, throughout small runoff events, and during early portions of large events. Later, Zuecco et al. (2015) presented a method for the quantitative description of the hysteretic behavior of runoff water chemical/isotopic composition at the event timescale suitable for automatic classification. They recognized eight types of hysteretic loops including two basic clockwise and anticlockwise patterns.

Tesar et al. (2004) examined relations between the soil water regime and runoff formation at the Liz catchment. They identified two distinct zones, a shallow soil profile and a deep drainage layer, each with specific rainfall-runoff transformation mechanisms. First, rainwater moves vertically through the soil to recharge the drainage layer, then water flows on the surface of sloping less permeable horizon to the stream. The relative importance of both mechanisms during runoff formation changes according to the actual soil water conditions, which results in accumulation and percolation phases of the catchment runoff. Regarding the percolation phase, Tesar et al. (2004) proposed that instability driven flow mechanism could be responsible for sudden rapid vertical transport of water to the drainage layer and subsequently to the stream. The manifestation of such mechanism at the catchment scale is similar to the threshold behavior related to bedrock topography control mechanism (known as fill and spill behavior, Trompvan Meerveld and McDonnell, 2006). Weekly monitoring of the stable $18 \mathrm{O}$ isotope in water at the Liz catchment was established in 2009 (Urban, 2014). This data set has not been thoroughly examined yet. Effect of the analysis could be enhanced by confrontation with results from more intensely studied catchment Uhlirska.

The first studies dealing with runoff formation at Uhlirska (e.g., Cislerova et al., 1998; Sanda and Cislerova, 2009) highlighted the correlation between the hillslope soil moisture and subsurface runoff and the total outflow from the catchment. Based on multiple regression analysis, Hrncir et al. (2010) presented dynamic thresholds of rainfall totals controlling the magnitude of stormflow at hillslope and catchment scales. Sanda et al. (2009) analyzed a selected summer stormflow episode using water isotopes and $\mathrm{SiO}_{2}$. The separation of the catchment hydrograph revealed a significant pre-event water component (more than 75\%), whereas the subsurface stormflow from the shallow soil at the hillslope transect contained about $50 \%$ of the pre-event water. These results accent importance of the water mixing within the soil profile as well as the role of the 
near-stream zones and/or valley aquifer in the catchment-scale runoff generation.

Stable isotopes and $\mathrm{SiO}_{2}$ content in the outflow from the hillslope transect and streamflow at Uhlirska were analyzed for a set of 20 rainfall-runoff events by Sanda et al. (2014). The results indicate that the rising limb of the outflow hydrograph at the hillslope trench scale is dominated by event water via fast preferential flow while at the catchment scale the rise of the stream discharge is dominated by pre-event water. The general concept of runoff formation presented by Sanda et al. (2014) includes the rainwater recharging the hillslope groundwater which subsequently contributes to the groundwater in the granitic sediments below Histosols in a riparian wetland. Alternatively, the subsurface runoff from the shallow hillslope soil is conducted in both man-made and natural surface channels to the stream. All studies reveal that Uhlirska catchment represents a catchment type with a significant effect of valley aquifer (i.e., so-called groundwater supplied wetland).

Blazkova et al. (2002) applied simple hydrological model TOPMODEL to predict water table levels at Uhlirska. Major runoff mechanism contributing to a rapid surface runoff in the model were variable source areas in the valley. Vogel et al. (2010) used the model based on Richards' equation for vertical soil water flow and the advection-dispersion equation for transport of the stable isotope to study the role of preferential flow in the formation of shallow subsurface runoff at the hillslope. The applied modeling approach explained the process of mixing between the new rainfall-event water and the old preevent water reasonably well and confirmed the critical importance of the preferential pathways for the formation of subsurface runoff at the hillslopes. In the follow-up modeling study, Dusek et al. (2012) estimated that the pre-event water forms $47-74 \%$ of the subsurface runoff (which is in good agreement with experimental results of Sanda et al., 2009).

Finally, Dusek and Vogel (2016) concluded on the basis of simulation results that there is no single-valued rainfall threshold for the activation of preferential flow and initiation of stormflow at Uhlirska. The rainfall amount needed to initiate stormflow varied, depending greatly on initial hillslope saturation, initial spatial distribution of soil water, and rainfall distribution in time.

The current study aims (i) to compare results of long-term isotope sampling conducted at two forested headwater catchments in Central Europe, (ii) to analyze contribution of event and pre-event water to the catchment direct outflow, and (iii) by confronting results from the two catchments, to gain new insight into the role of different runoff mechanisms in the stream discharge formation at the headwater catchments of interest.

\section{MATERIAL AND METHODS \\ Liz catchment}

Liz catchment (average altitude $941 \mathrm{~m}$ a. s. 1.; average annual temperature $6.3^{\circ} \mathrm{C}$; average annual precipitation $861 \mathrm{~mm}$; and drainage area $0.99 \mathrm{~km}^{2}$ ) lies in the south-western part of the Czech Republic in the Bohemian Forest. The catchment belongs to hillslope-type catchments with negligible influence of riparian zones. The soil type is the oligotrophic forest Eutric Cambisol developed upon biotite paragneiss bedrock. The catchment is fully covered by acid spruce-beech forest. The majority of trees are 94 years old with a height of about $28 \mathrm{~m}$ and a diameter of about $40 \mathrm{~cm}$. Two automatic monitoring stations (in an open area and at the spruce forest bottom) for continuous measurements of air and soil temperatures, soil water pressure, and soil water content are operated. In order to describe the variability of the soil water regime in the catchment, four additional automatic soil-water monitoring stations have been set at sites with different vegetation cover and altitude. Precipitation is measured in both the open area and the spruce and beech forest (throughfall and stemflow). Stream discharge is recorded in the closing profile of the catchment.

\section{Uhlírská catchment}

Uhlirska catchment is located in the Jizera Mountains, northern Bohemia $\left(819 \mathrm{~m}\right.$ a. s. $1 . ; 4.7^{\circ} \mathrm{C} ; 1400 \mathrm{~mm} ; 1.78 \mathrm{~km}^{2}$ ). Deluviofluvial granitic sediments in the valley bottom areas (riparian zones/wetlands) are surrounded by gentle hillslopes with shallow soils developed on crystalline bedrock. The soils at hillslopes are shallow sandy loams classified as Cryptopodzols and Podzols. A sharp transition to the bedrock starts at the depth of about $70 \mathrm{~cm}$. Histosols are typical for the bottom of the valley with groundwater-supplied wetland. Headwater regions in the Jizera Mts. represent a typical Central European temperate boreal zone with a large amount of precipitation, humid climate, and a recent history of nearly complete deforestation due to acid rain in the 1980s and 1990s. At present, the Uhlirrská catchment is covered mostly with sparse young forest dominated by spruce trees ( 22 years old and the average height of $15 \mathrm{~m}$ ). Forest openings are covered mainly with grass (height about $30 \mathrm{~cm}$ ). The catchment has been equipped with an extensive monitoring and sampling network. Monitored variables include soil water pressure and soil water content, air and soil temperatures, atmospheric pressure and humidity, net radiation, wind velocity, precipitation, sap flow in spruce trees, subsurface runoff and stream discharge at the catchment outlet. Several perennial groundwater boreholes are also monitored.

\section{Sample collection}

The present study utilizes the ${ }^{18} \mathrm{O}$-isotope data measured at Liz and Uhlirska catchments over the period of 2009-2015 and 2006-2015, respectively. The $\delta^{18} \mathrm{O}$ values were determined for (i) precipitation collected from the rain gauges (or from snowfall and snowpack samples during winter), (ii) groundwater collected from wells and a spring, and (iii) stream water collected at the watershed outlets.

At the Liz catchment, the precipitation samples were collected as weekly cumulative samples (rainfall during vegetation season and snow during winter). In order to minimize the evaporation from the free water level of a sample, a few oil droplets were added to the collecting bottle. During the winter seasons, precipitation samples were collected using a storage gauge. The stream water at the outlet section and the spring was sampled weekly; the instantaneous samples were taken manually.

At the Uhlirska catchment, the precipitation sampling frequency during vegetation season was related to the precipitation intensity; the samples were collected at daily intervals, provided that the amount of rainfall since the previous sampling had exceeded $5 \mathrm{~mm}$. During winter, weekly cumulative precipitation was sampled using a storage gauge. The stream water at the catchment outlet section was sampled daily using an automatic sampler (ISCO Teledyne Technologies, Inc.). Sampling became more frequent during major rainfall events (6-hour interval). The groundwater in four groundwater boreholes was sampled monthly; the instantaneous samples were collected manually. 


\section{Isotope analysis}

Liquid water isotope analyzer (LWIA) utilizing the principle of laser spectroscopy (LGR Inc., $2^{\text {nd }}$ generation) for determination of stable isotope concentrations $\left({ }^{18} \mathrm{O}\right.$ and $\left.{ }^{2} \mathrm{H}\right)$ was used. The ${ }^{18} \mathrm{O}$ content was measured with the manufacturer declared precision of $\delta^{18} \mathrm{O} \pm 0.2 \%$. The $\delta^{18} \mathrm{O}$ values (given in parts per thousand) represent relative deviations of the measured ${ }^{18} \mathrm{O} /{ }^{16} \mathrm{O}$ ratios from the isotopic composition of the Vienna Standard Mean Ocean Water (V-SMOW).

\section{RESULTS AND DISCUSSION}

Basic hydro-meteorological time series analysis

Runoff dynamics of the two catchments differ obviously (Fig. 1, note the difference in vertical axes scales). At Liz, only a limited number of significant precipitation or snowmelt events induce substantial discharge reaction accompanied by clearly detectable baseflow increases (represented by the lower envelope of the discharge series). Otherwise, the regular precipitation induces minute variations of the catchment discharge. At Uhlirska, the stream reacts more vividly to precipitation. The scale of the event-related stream discharge variations is about five times bigger than at Liz (considering the specific discharge). Regarding the baseflow dynamics, the range of the specific discharge variations is about the same as at Liz, but the time scale of baseflow decline is shorter at Uhlirska. At the same time, a higher frequency of baseflow recharge at Uhlirska is likely related to the more plentiful precipitation input at this catchment.
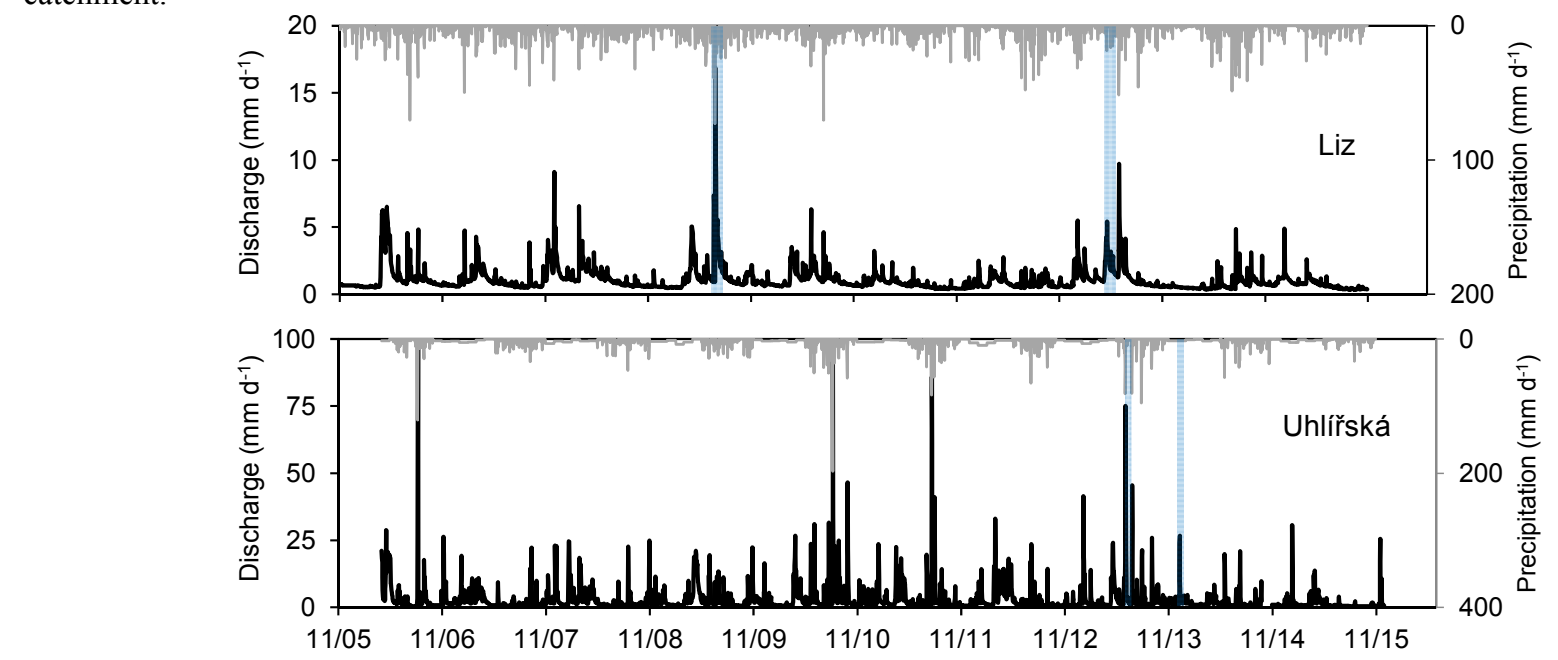

Autocorrelation functions (ACF) of daily average outflow data series (Fig. 2) illustrate different outflow regime of the two catchments under study. The longer ACF relaxation time found at the Liz catchment reflects the dominance of the slow, baseflow-related runoff processes at this catchment. In consequence, isotopic signature of few major rainfall events can be found in the streamflow isotopic data despite relatively low sampling frequency (once a week). For Uhlirska, the shorter ACF time exposes significance of the fast outflow processes in the stream discharge formation. Moreover, the absence of seasonal autocorrelation component at Uhlirska also indicates highly event-dominated stream flow dynamics. On the other hand, distinct seasonal autocorrelation fluctuation detected for the Liz catchment further supports the significance of baseflowrelated runoff process and stable seasonal pattern of groundwater recharge.

\section{Isotope concentration data analysis}

The two principle factors that control the isotopic content of precipitation are the temperature of condensation of the precipitation and the degree of a rainout of the air mass. Local water meteoric lines (LWML) of both sites differ from Global meteoric water line (Craig, 1961) in both slope and deuterium intercept (Fig. 3). However, the slope differences of -0.18 and -0.24 are not uncommon (Holko et al., 2012). In general, LWML's are very similar, thus, both catchments receive isotopically equivalent rainfall/snowfall input.

Fig. 1. Daily precipitation and daily specific discharge at Liz and Uhlirska (monthly precipitation averaging for Uhlirska during winter). Highlighted rainfall-runoff episodes are later used for detailed analysis.
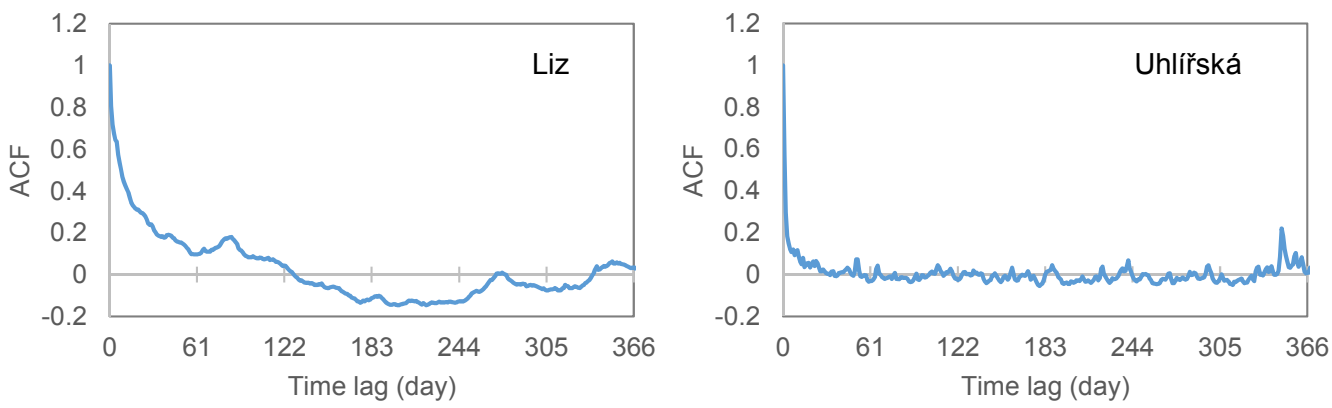

Fig. 2. Autocorrelation function (ACF) of stream discharge data (daily averages from 2007-2014). 

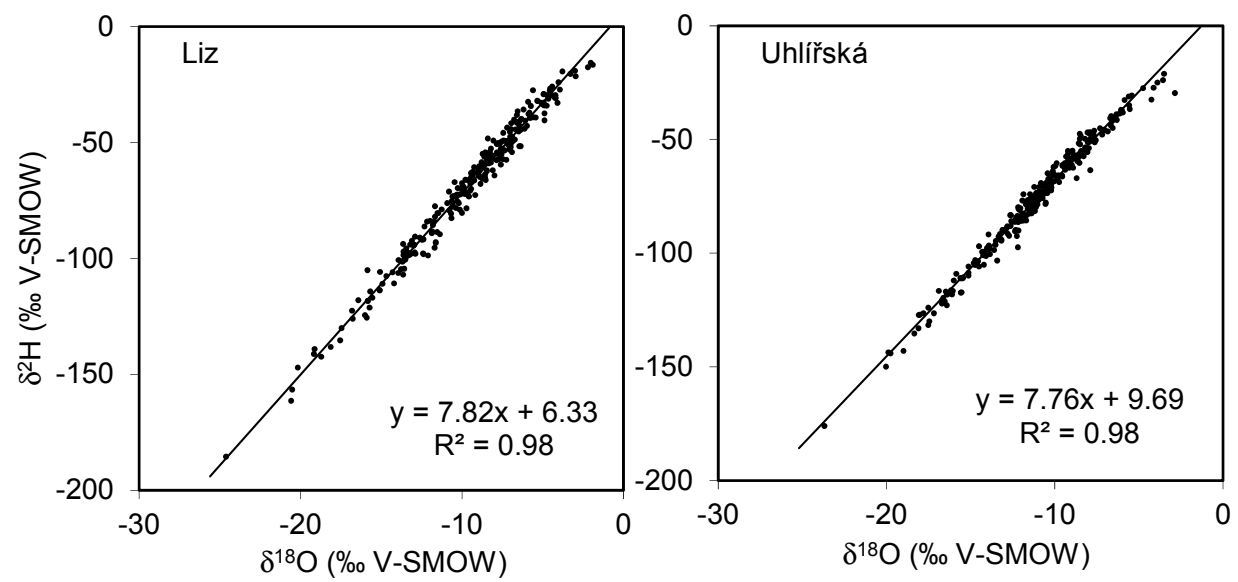

Fig. 3. Local meteoric water lines defined by the isotopic composition of precipitation. Isotope concentrations presented were measured in 2009-2015 for Liz catchment (weekly composed precipitation), and in 2006-2014 for Uhlirska catchment (monthly composed rainfall in summer and weekly composed precipitation in winter).
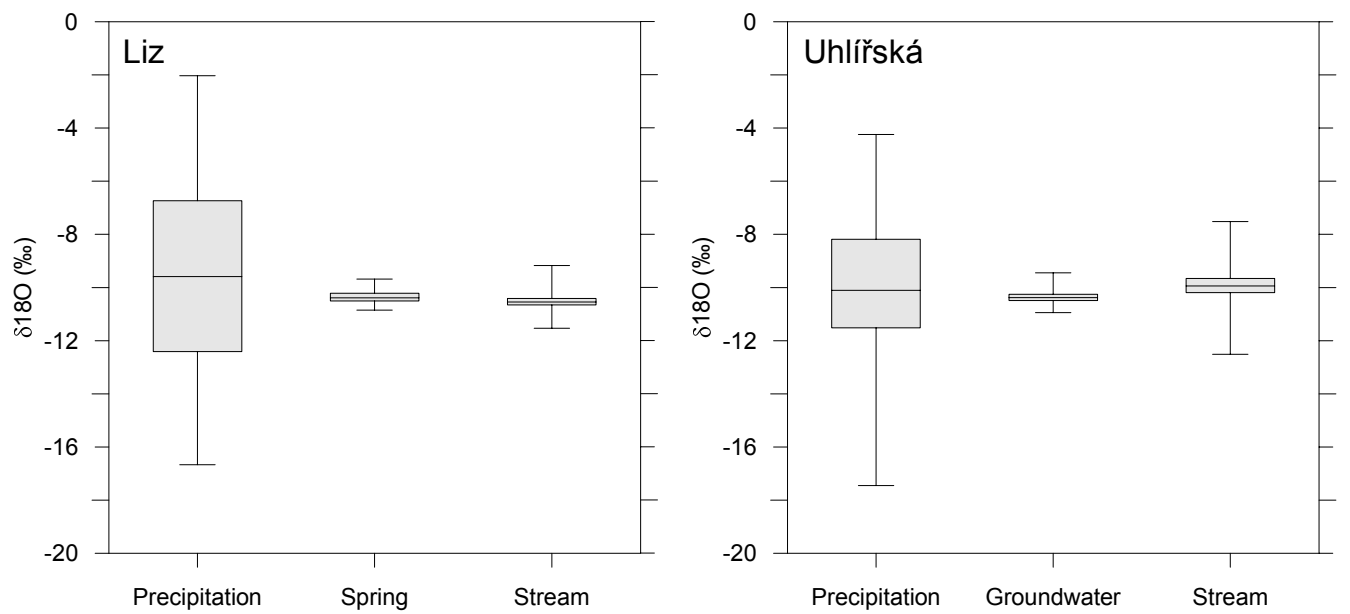

Fig. 4. $\delta^{18} \mathrm{O}$ of water samples collected in both catchments - precipitation, groundwater/spring water, and surface water in the stream. For each dataset, median, lower and upper quartile, and extremes are displayed. Data covering full hydrological years (Liz 2010-2015 and Uhlirska 2007-2015) were included. Monthly cumulative samples of precipitation, weekly instantaneous samples of stream water and spring (Liz), and monthly instantaneous samples of groundwater at (Uhlirska) are presented.

Fig. 4 provides an overview of isotopic composition variability of water samples taken from three main hydrological compartments - precipitation, groundwater/spring water and stream. A similar trend in variability is obvious in both catchments. The interquartile range of precipitation data is five to ten times bigger than that of stream water data. The high variability of precipitation isotopic concentration reflects seasonal fluctuation (monthly samples are presented); summer precipitation is isotopically heavier $\left(\delta^{18} \mathrm{O}\right.$ value is higher, meaning the heavy water deficit is smaller), winter precipitation is isotopically lighter $\left(\delta^{18} \mathrm{O}\right.$ value is lower). The stable values observed in groundwater, spring and stream are related to mixing of water with various residence times within the catchment (contribution of various runoff pathways).

Comparing both catchments, a higher isotopic variability of the monthly precipitation was observed at Liz. A lower median value of ${ }^{18} \mathrm{O}$ concentrations in precipitation was detected at Uhlirska, which is in accord with a general finding that greater amount of rainfall received $(1400 \mathrm{~mm} / \mathrm{year}$ for Uhlirska and $861 \mathrm{~mm} /$ year for Liz) and higher altitude (difference in site's altitudes about $122 \mathrm{~m}$ ) are often associated with lower $\delta^{18} \mathrm{O}$ and $\delta^{2} \mathrm{H}$ values of the liquid forms of precipitation (Dansgaard, 1964; Kendall et al., 1995).
Variability of ${ }^{18} \mathrm{O}$ concentrations in the catchment discharge is considerably higher at Uhlirska, which reflects the intensive contribution of fast event-water runoff.

For the Liz catchment, the median of the isotopic composition of precipitation $(-9.59 \%)$ is significantly higher than median values of spring and streamflow $(-10.39 \%$ and $-10.54 \%$ ). This is probably due to the transpiration loss reducing the amount of isotopically heavier summer precipitation water available for groundwater recharge. Thus, streamflow is predominantly generated from well-mixed groundwater reservoir recharged mostly by isotopically lighter winter precipitation (during snowmelt events). At the same time, the stream water at the catchment outlet section is isotopically lighter than at the spring, while the interquartile range stays unchanged. Thus, it seems that relative contribution of isotopically lighter winter precipitation grows along the stream.

For the Uhlirska catchment, the $\delta^{18} \mathrm{O}$ median of groundwater $(-10.38 \%)$ is lower than the median of the precipitation $(-10.10 \%)$. This accords with the hypothesis that groundwater origins mainly from isotopically lighter winter precipitation, (intensive groundwater recharge during snowmelt events). However, in contrast to $\mathrm{Liz}$, the $\delta^{18} \mathrm{O}$ median of stream water $(-9.94 \%)$ is slightly higher than that of precipitation. Overall higher $\delta^{18} \mathrm{O}$ values in stream water compared to groundwater 


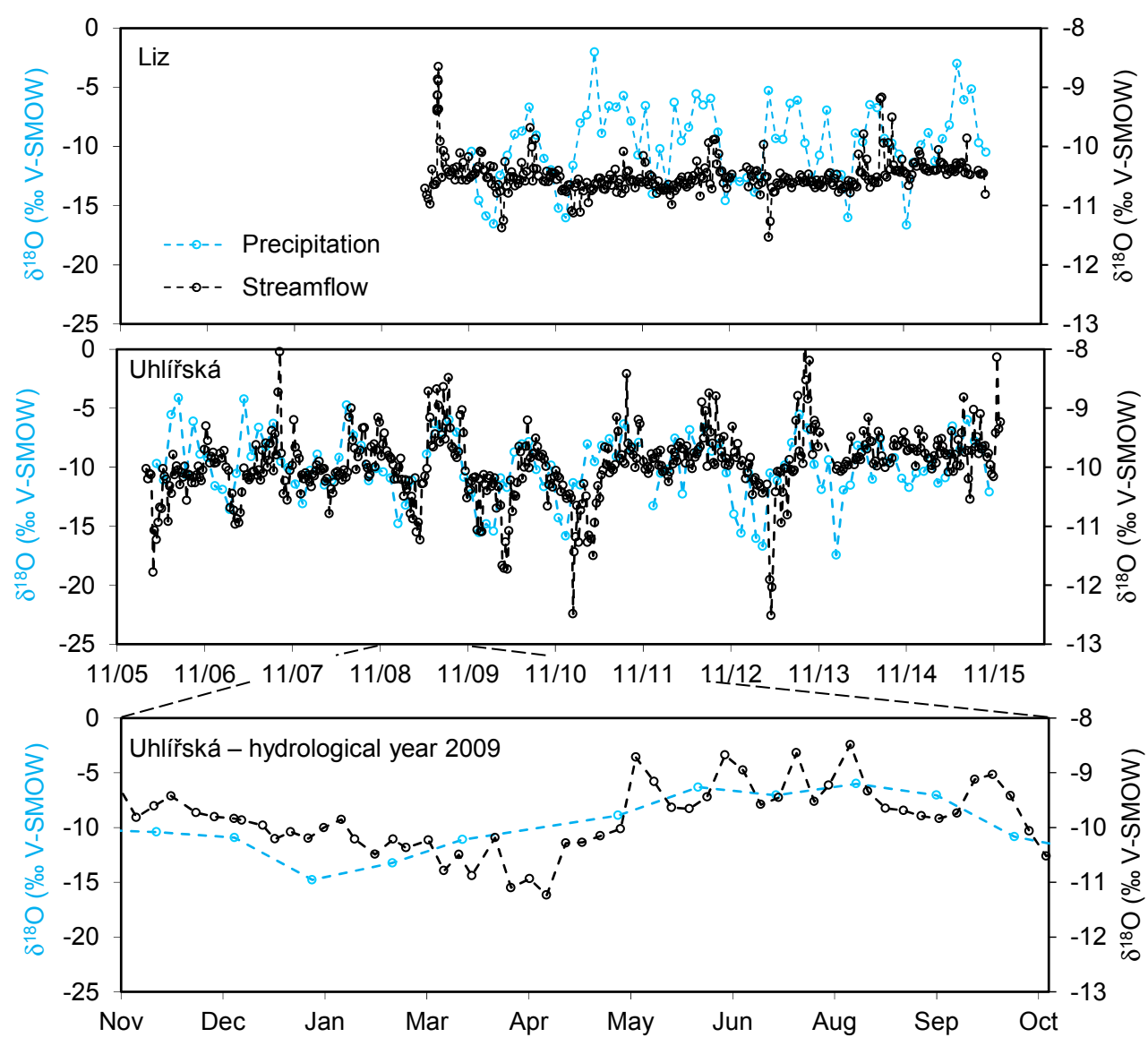

Fig. 5. Time development of isotope concentrations at both catchments (Liz and Uhlirska). Different scales are used for precipitation and streamflow data. The bottom panel shows data observed at Uhlirska during the hydrological year 2009 in detail.

can be explained by high frequency of rainfall-runoff events with substantial contribution of event water to direct runoff during summer. This result may be partly influenced by the fact that discontinuities in the stream water sampling at Uhlirska are more frequent during winter time (e.g., no data for December 2013).

Temporal variation of the isotopic composition of precipitation and catchment discharge is presented in Fig. 5. Intensive isotopic signal attenuation between precipitation and discharge is observed at both catchments (note different concentration scales for precipitation and discharge). Obviously, considerably stronger transformation occurs at Liz (Fig. 5), where the isotopic signature in streamflow is almost stable, defining a clear curve of slight seasonal variations. Only a few episodes of outflow with the contrasting isotopic composition can be detected.

At Uhlirska (Fig. 5), the variability of isotopic concentration in discharge is markedly greater in both components, seasonal and episodic. Moreover, the episodic variations are more frequent. The data show a high degree of similarity between time series of isotopic concentration in precipitation and streamflow. Seasonal variations of both are closely related; note, for instance, the absence of a distinct isotopic decline in winter 2011-2012 observed in both data series. Fast response to isotopically heavy summer storms (stream maxima during summer) and postponed reaction to winter isotopically light precipitation (stream isotopic minima related to snowmelt events, mostly during spring) are illustrated by the 2009 data in Fig. 5.

The abnormally low amount of snow during two consecutive winters 2013-2014 and 2014-2015 induced increasing role of isotopically heavy summer precipitations in the discharge, which is apparent at both catchments (Fig. 5). Stream water in the hydrological years 2014 and 2015 was isotopically heavier by $0.16 \%$ at Liz and by $0.35 \%$ at Uhlirska in average than during four previous years.

\section{Residence times}

Previously, based on observed seasonal isotopic variations in precipitation, discharge, and groundwater, Sanda et al. (2014) evaluated residence times of water in the Uhlirska catchment. Their approach (based on the methodology of Maloszewski and Zuber, 1996) relied on crude simplification of the runoff processes, considering the exponential distribution of residence times and invariable input of water in time (constant precipitation intensity with variable isotopic composition). Mean residence time was then determined based on attenuation of the seasonal variation of isotope concentration between the input water (i.e. precipitation) and water leaving the system (i.e. groundwater or stream water). The resulting mean residence time was greater than 5 years for water recharging the groundwater at the valley bottom, about 12 months for water forming the baseflow, and 4.4 months for any water contributing to the stream discharge at the catchment outlet.

Applying the same methodology to Liz, Urban (2014) estimated mean residence time of the whole catchment to be 3.46 years but at the same time concluded that water residence time is significantly uncertain because of the low isotopic variability of stream discharge.

However, the meaning of the obtained residence times is questionable. For example, it is clear that the water input inten- 
sity has seasonal variations which not only cause a discrepancy between the mean isotopic composition of the precipitation and the mixed water at the output but also reduces the amplitude of the output isotopic signals. The consequence is an overestimation of the mean residence time determined. Other assumptions, such as linearity and homogeneity of the system, are violated too. Recently, Kirchner (2016a, 2016b) proposed the young water fraction as a better measure of transit times, which is more appropriate for spatially heterogeneous catchments. However, advanced analysis of the catchments' transit times is outside the scope of the present study.

\section{Event water contribution to direct runoff}

For each catchment, two significant rainfall-runoff episodes were selected with contrasting isotopic composition of the input water (rainfall or snowmelt) (Table 1). The input water was either isotopically heavy, causing increase of $\delta^{18} \mathrm{O}$ in stream, or isotopically light, causing decrease of $\delta^{18} \mathrm{O}$ in stream. The isotope concentration in the stream was used to evaluate the contribution of the event water (water from the incident precipitation or snowmelt, "new water") to the catchment discharge. Plots of the isotopic composition of stream water as a function of the stream discharge illustrate the development of the "new water" relative contribution during the runoff event (Figs. 6 and 7). For this purpose, the episodes had to be clearly separated from previous runoff events and the isotopic composition of their incident rainfall had to be approximately uniform (the latter requirement is often difficult to meet). To calculate relative contribution of the "new water" to the catchment discharge presented in Table 1, the stream water was assumed to be a simple mixture of "new water" and of the water present in the catchment before the episode (pre-event water, "old water"). The isotopic composition of "old water" contributing to the outflow was assumed constant throughout the runoff episode (defined by the initial stream water isotope content).

Table 1. Characteristics of rainfall-runoff events. Symbol $\phi$ stands for the runoff coefficient (runoff amount divided by precipitation amount).

\begin{tabular}{|c|c|c|c|c|c|c|c|c|c|c|c|}
\hline & & \multicolumn{2}{|c|}{ Initial streamflow } & \multicolumn{2}{|c|}{ Incident precipitation } & \multicolumn{2}{|c|}{ Discharge } & \multicolumn{2}{|c|}{ New water runoff } & \multicolumn{2}{|c|}{ New water in discharge } \\
\hline & & $\begin{array}{l}\text { disch. } \\
(\mathrm{mm} / \mathrm{d})\end{array}$ & $\begin{array}{l}\delta^{18} \mathrm{O} \\
(\% \mathrm{o})\end{array}$ & $\begin{array}{l}\text { amt. } \\
(\mathrm{mm})\end{array}$ & $\begin{array}{l}\delta^{18} \mathrm{O} \\
(\%)\end{array}$ & $\begin{array}{l}\text { amt. } \\
(\mathrm{mm})\end{array}$ & $\begin{array}{c}\phi \\
(\%)\end{array}$ & $\begin{array}{l}\text { amt. } \\
(\mathrm{mm})\end{array}$ & $\begin{array}{c}\phi \\
(\%)\end{array}$ & $\begin{array}{c}\max . \\
(\%)\end{array}$ & $\begin{array}{c}\text { cumul. } \\
(\%)\end{array}$ \\
\hline.. & $22 / 6-14 / 72009$ & 0.88 & -10.59 & 275.5 & -6.93 & 144.7 & 53 & 38.2 & 14 & 53 & 30 \\
\hline$\exists$ & $8 / 4-6 / 52013$ & 0.92 & -10.52 & 154.9 & -12.06 & 73.4 & 47 & 27.2 & 18 & 66 & 37 \\
\hline$\frac{\pi}{\vec{w}}$ & $21 / 6-30 / 62013$ & 1.01 & -10.07 & 145.5 & -12.37 & 96.9 & 67 & 18.9 & 13 & 41 & 19 \\
\hline 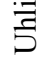 & 2/9-9/9 2013 & 0.93 & -9.76 & 84.9 & -4.56 & 45.1 & 53 & 19.3 & 23 & 57 & 43 \\
\hline
\end{tabular}
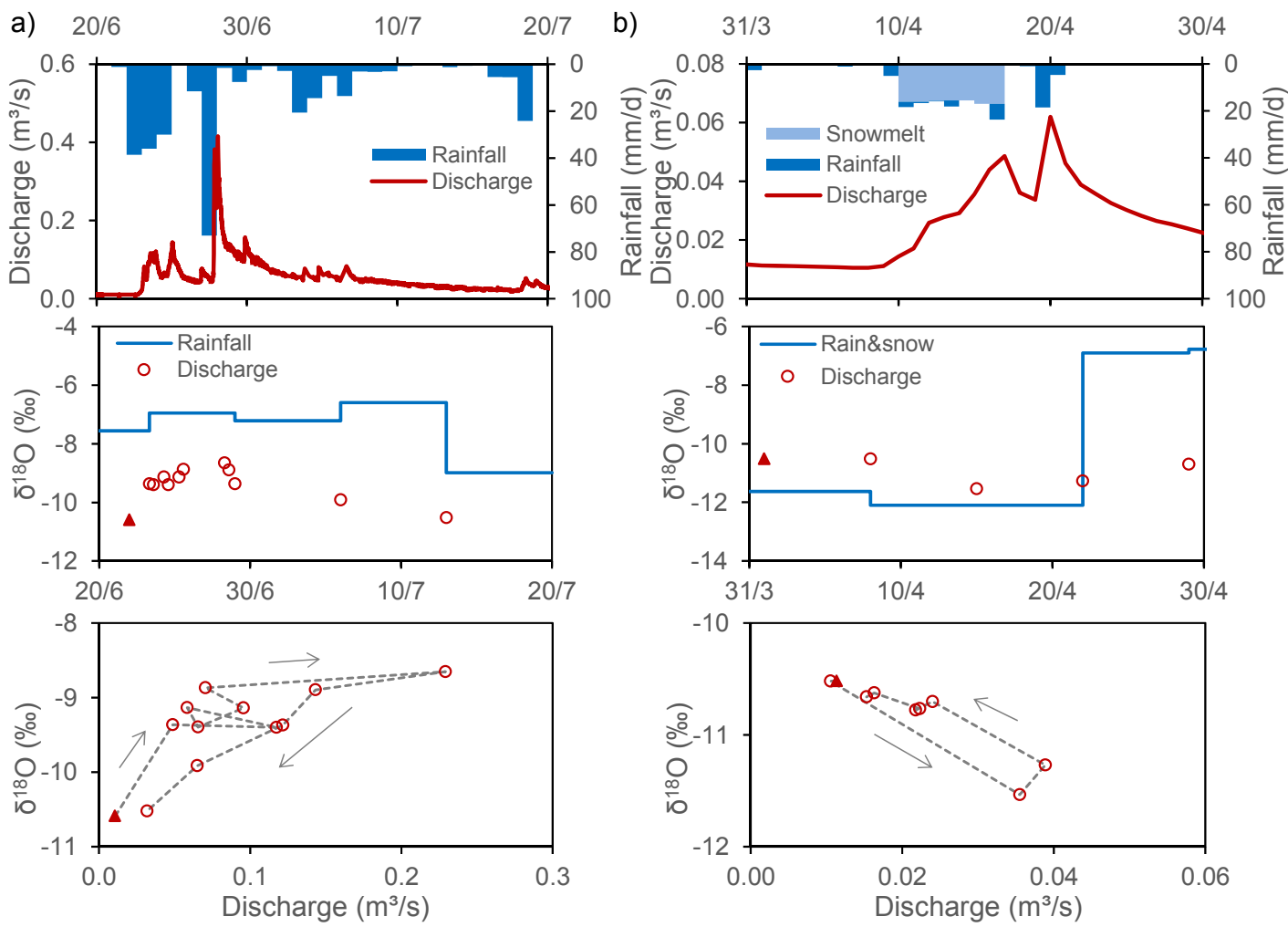

Fig. 6. Selected major runoff events at the Liz catchment induced by (a) isotopically heavy rainfall and (b) isotopically light snowmelt: incident precipitation/snowmelt intensity and stream discharge; ${ }^{18} \mathrm{O}$ concentration in precipitation/snowmelt and streamflow; streamflow isotopic composition as a function of the stream discharge. The initial (background) value of ${ }^{18} \mathrm{O}$ concentration is marked with a triangle. 
a)
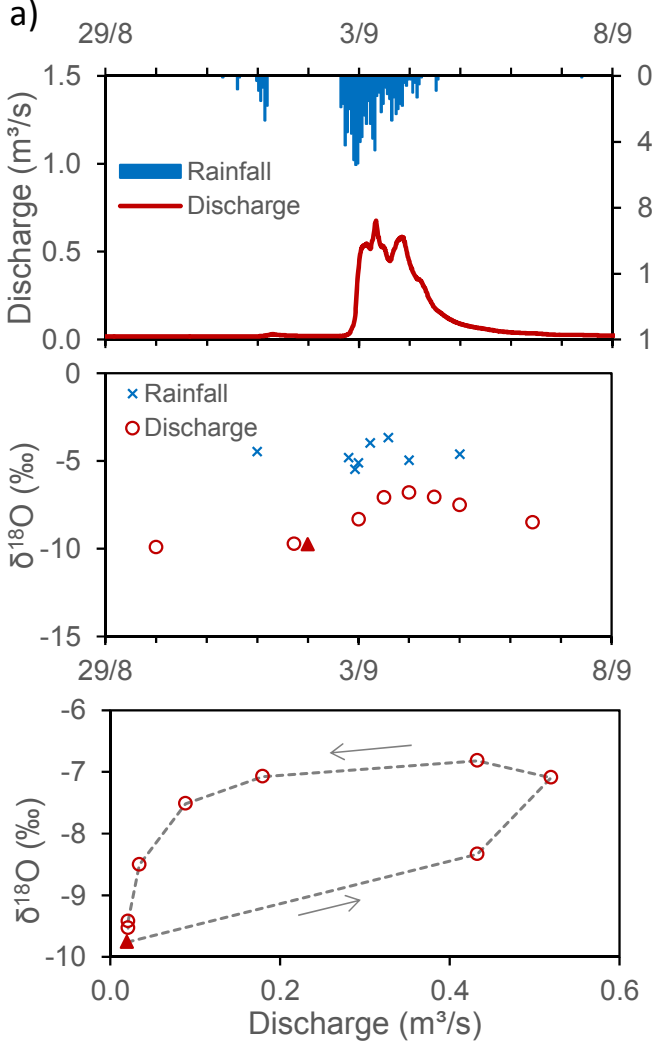

b)
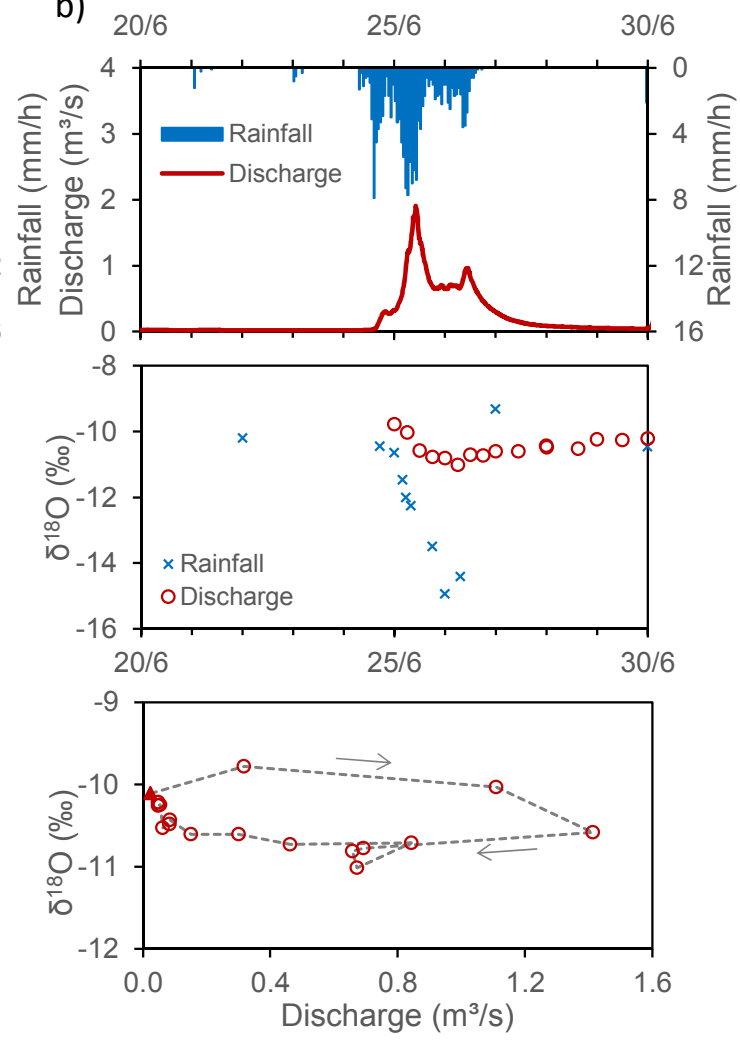

Fig. 7. Selected major runoff events at the Uhlirska catchment induced by (a) isotopically heavy rainfall and (b) isotopically light rainfall: incident precipitation intensity and stream discharge; ${ }^{18} \mathrm{O}$ concentration in precipitation and streamflow; streamflow isotopic composition as a function of the stream discharge. The initial (background) value of ${ }^{18} \mathrm{O}$ concentration is marked with a triangle.

For Liz catchment, a clockwise hysteretic relationship between the stream discharge and its isotope concentration was identified during the isotopically heavy outflow event (Fig. 6a) and a counterclockwise relationship during the isotopically light event (Fig. 6b). These results imply that the relative portion of the event water in the catchment discharge is greater during early phases of the runoff events (considering the constant isotopic composition of both the rainfall/snowmelt water and the catchment "old water"). Unfortunately, the available data do not provide more episodes suitable for this kind of analysis (weekly sampling does not capture development during standard runoff episodes).

Opposite behavior was detected at Uhlirska: a counterclockwise hysteretic relationship between the stream discharge and its isotope concentration was identified above isotopic mean and clockwise relationship below the mean (Fig. 7). Thus, the percentage of the "new water" in the catchment discharge is greater during the later stages of the runoff event, on the falling limb of the hydrograph. This behavior was identified during the majority of rainfall-runoff episodes observed at Uhlirska (for example 18 out of 20 episodes studied by Sanda et al., 2014) and thus, can be assumed characteristic. The implied reason for this behavior is, paradoxically, that the pre-event water reaction to the rainfall event is faster than the direct runoff of new water. The mechanism leading to this fast response of the pre-event water has yet to be explained.

Assuming simple mixing of water from two isotopically stable sources, an approximate separation of the event water from the baseflow can be done. The results are summarized in Table 1. The limited number of studied episodes hinders any sophisticated reasoning regarding differences between the catchments or the impact of initial conditions or incident rain- fall/snowmelt intensity or volume. It can be argued that at both catchments only less than $25 \%$ of the rainfall/snowmelt contributed to the direct runoff. This new water represented less than $50 \%$ of the cumulative discharge of each episode $(19-43 \%)$. The maximum observed an instantaneous fraction of the new water in the discharge was $66 \%$.

\section{Direct runoff formation mechanisms}

Contrasting results for the two catchments are related to differences in their geomorphological character. The Liz catchment is formed by a hillslope with the base at the stream. The stream baseflow is supplied from an unconfined aquifer. The Uhlirska catchment is more complicated, with hillslopes separated from the stream by wetlands in the valley bottom. The stream baseflow is supplied mostly from shallow groundwater of the wetland, which is recharged partly by rainfall and direct hillslope runoff, and partly by the deeper (semi)confined aquifer.

The phenomenon of fast activation of the pre-event water in the direct runoff observed in the stream at Uhlirska has been described by Sanda et al. (2009). The geochemical composition of subsurface hillslope discharges observed in the trench at Uhlirska (Sanda et al., 2014) reveals an opposite behavior, i.e. decreasing contribution of the event water during the runoff episode (slow activation of pre-event water). This finding was related to the preferential flow in the soil profile. Sanda et al. (2014) concluded that at the scale of the catchment, preferential flow effects are overridden by displacement of pre-event water from the hillslope soil matrix.

The fact that the same behavior (slow activation of pre-event water) is observed at the Liz catchment is interesting. It implies 
that the catchment direct runoff at Liz may be governed by similar processes as the episodic runoff from the soil profile observed at Uhlirska. Another similarity of the Liz catchment with the hillslope at Uhlirska can be found in the frequency of the significant direct runoff events observed.

The dominant role of the water originating at the hillslope in the stream discharge at Uhlirska was assumed based on a comparison of the dynamics and volumes of discharge observed at both scales (Sanda and Cislerova, 2009). However, the source of the pre-event water dominating the catchment outflow at the beginning of the runoff events may be different. It is possible, that the preferential flow of the event water detected in the experimental trench is characteristic of the whole hillslope and the fast pre-event water mobilization is produced within the wetland zone separating the slopes from the stream. Considering the two catchments under study, the presence/absence of riparian zone with wetlands is a marked difference that may underlie the dissimilarities in the runoff formation.

\section{Comparison with results found at other sites}

Wetlands play an important role in runoff-generation mechanism in headwater catchments around the world (e.g., Camacho Suarez et al., 2015; McCartney et al., 1998). Bullock and Acreman (2003), in their review, concluded that the impact of these regions on flood flow formation was ambiguous. They also stated that headwater wetlands tend to be saturated, thus causing quick responses of recipients to rainfall, which is in agreement with our observations at Uhlirska (faster response of the riparian zone at the Uhlirska catchment vs. more gradual response of the wetland-free catchment Liz). In our opinion, some of the ambiguous results reported for wetlands in the literature could be attributed to different local topography and soil conditions.

In the present study, similarly to Tetzlaff et al. (2009) or Hrachowitz et al. (2009), using long-term tracer data at two contrasting catchments helped to examine the relative influence of topography on runoff formation. Our finding that the preevent water dominats the catchment streamflow discharge at the beginning of runoff events at Uhlirska is consistent with the working hypothesis of Stockinger et al. (2014) formulated for the Wüstebach catchment according to which pre-event water stored in the riparian zone gets activated fast during an event as it does not need to travel far.

\section{CONCLUSIONS}

Natural stable isotope tracer was used to study the water movement in the small experimental catchments Liz in the Bohemian Forest and Uhliřská in the Jizera Mountains, Czech Republic. Comparison of the data exposes differences in the runoff formation at these two catchments, improving our understanding of their hydrological functioning.

The two catchments exhibit different hydrological behavior. Liz is a simple hillslope-type catchment with baseflowdominated stream discharge. At Uhlirska, hillslope parts are combined with wetlands in the valley bottom, and the stream discharge is strongly affected by rainfall-runoff events. While the baseflow discharge variations are similar in both catchments (considering the specific discharge values), the event-related stream discharge variations at the Uhlirska catchment are about five times bigger and significantly more frequent than at Liz.

The different character of the stream discharge response to rainfall events is reflected also in the different dynamics of the stream isotopic composition variations. Considerably less variable series was obtained at the Liz catchment outlet, where the isotopic signal is almost stable, containing only a few events with contrasting isotopic composition.

Contrasting hydraulic behavior of the two catchments during the major rainfall-runoff events was disclosed using simple baseflow separation method (assuming constant isotopic composition of old water). At Uhlirska, the percentage of the catchment direct runoff formed by the event water is greater during later stages of the runoff event (on the falling limb of hydrograph) than during the initial, rising-discharge stage. In contrast, at Liz, the event water related fraction of the catchment direct runoff is greater on the rising limb of the hydrograph and then lowers. Interestingly, the Liz catchment behavior is similar to the phenomena described previously for the hillslope runoff at the Uhlirska catchment. The difference between the hillslope and stream at Uhlirska is likely related to hydraulic functioning of the riparian wetland. Summarizing findings for both catchments, only less than $25 \%$ of the rainfall/snowmelt contributed to the direct runoff and this new water represented less than $50 \%$ of the event cumulative discharge.

To further improve understanding of hydraulic functioning of the Uhlirska catchment, more information about the hydraulic communication between hillslope and riparian zone compartments is needed.

Acknowledgement. The research was funded by the Czech Science Foundation, project No. 14-15201J.

\section{REFERENCES}

Blazkova, S., Beven, K., Tacheci, P., Kulasova, A., 2002. Testing the distributed water table predictions of TOPMODEL (allowing for uncertainty in model calibration): The death of TOPMODEL? Water Resour. Res., 38, 11, 1257. DOI: 10.1029/2001WR000912.

Bullock, A., Acreman, M., 2003. The role of wetlands in the hydrological cycle. Hydrol. Earth Syst. Sci., 7, 358-389.

Burns, D.A., Plummer, L.N., McDonnell, J.J., Busenberg, E., Casile, G.C., Kendall, C. et al., 2003. The geochemical evolution of riparian ground water in a forested piedmont catchment. Ground Water, 41, 7, 913-925. DOI: 10.1111/j.1745-6584.2003.tb02434.x.

Camacho Suarez, V.V., Saraiva Okello, A.M.L., Wenninger, J. W., Uhlenbrook, S., 2015. Understanding runoff processes in a semi-arid environment through isotope and hydrochemical hydrograph separations. Hydrol. Earth Syst. Sci., 19, 4183-4199.

Cislerova, M., Sanda, M., Blazkova, S., Mazac, O., Grünwald, A., Zeithammerova, J., Tacheci, P., 1998. Ecological aspects of the water resources protection: Transport processes in a watershed affected by abrupt changes of runoff conditions (Jizera Mountains). Res. Rep. VaV/510/3/96-DÚ 01. Ministry of Environment of the Czech Republic, Prague. (In Czech.)

Craig, H., 1961. Isotopic variations in meteoric waters. Science, 133, 1702-1703.

Dansgaard, W., 1964. Stable isotopes in precipitation. Tellus, $16,4,436-468$.

Dincer, T., Payne, B.R., Florkows, T., Martinec, J., Tongiorg, E., 1970. Snowmelt runoff from measurements of tritium and oxygen-18. Water Resour. Res., 6, 110-124.

Dusek, J., Vogel, T., Sanda, M., 2012. Hillslope hydrograph analysis using synthetic and natural oxygen-18 signatures. J. Hydrol., 475, 415-427. DOI: 10.1016/j.jhydrol.2012.10.025. 
Dusek, J., Vogel, T., 2016. Hillslope-storage and rainfallamount thresholds as controls of preferential stormflow, J. Hydrol., 534, 590-605. DOI: 10.1016/j.jhydrol.2016.01.047.

Glynn, P.D., Plummer, L.N., 2005. Geochemistry and the understanding of ground-water systems. Hydrogeology J., 13, 263-287.

Holko, L., Dóša, M., Michalko, J., Kostka, Z., Sanda, M., 2012. Isotopes of oxygen-18 and deuterium in precipitation in Slovakia. J. Hydrol. Hydromech., 60, 4, 265-276.

Hrachowitz, M., Soulsby, C., Tetzlaff, D., Dawson, J.J.C., Dunn, S.M., Malcolm, I.A., 2009. Using longer term tracer data to understand transit times in contrasting headwater catchments. J. Hydrol., 367, 237-248.

Hrncir, M., Sanda, M., Kulasova, A., Cislerova, M., 2010. Runoff formation in a small catchment at hillslope and catchment scales. Hydrol. Process., 24, 2248-2256. DOI: 10.1002/hyp.7614.

Kendall, C., Sklash, M.G., Bullen, T.D., 1995. Isotope tracers of water and solute sources in catchments. In: Solute Modelling in Catchment Systems. J. Wiley \& Sons, New York, pp. 261-303.

Kirchner, J.W., Tetzlaff, D., Soulsby, C., 2010. Comparing chloride and water isotopes as hydrological tracers in two Scottish catchments. Hydrol. Process., 24, 1631-1645. DOI: 10.1002/hyp.7676.

Kirchner, J.W., 2016a. Aggregation in environmental systems Part 1: Seasonal tracer cycles quantify young water fractions, but not mean transit times, in spatially heterogeneous catchments. Hydrol. Earth Syst. Sci., 20, 279-297.

Kirchner, J.W., 2016b. Aggregation in environmental systems Part 2: Catchment mean transit times and young water fractions under hydrologic non-stationarity. Hydrol. Earth Syst. Sci., 20, 299-328.

Kurtz, A.M., Bahr, J.M., Carpenter, Q.J., Hunt, R.J., 2007. The importance of subsurface geology for water source and vegetation communities in Cherokee Marsh, Wisconsin. Wetlands, 27, 189-202.

Lamacova, A., Hruska, J., Kram, P., Stuchlik, E., Farda, A., Chuman, T., Fottova, D., 2014. Runoff trends analysis and future projections of hydrological patterns in small forested catchments. Soil \& Water Res., 9, 169-181.

Maloszewski, P., Zuber, A., 1996. Lumped parameter models for the interpretation of environmental tracer data. In: Manual on Mathematical Models in Isotope Hydrology. IAEA TEC DOC 910, Vienna, pp. 9-58.

McCartney, M.P., Neal, C., Neal, M., 1998. Use of deuterium to understand runoff generation in a headwater catchment containing a dambo. Hydrol. Earth Syst. Sci., 2, 65-76.

McGlynn, B., McDonnell, J., Stewart, M., Seibert, J., 2003. On the relationships between catchment scale and streamwater mean residence time. Hydrol. Process., 17, 175-181.
McGuire, K.J., McDonnell, J.J., 2006. A review and evaluation of catchment transit time modeling. J. Hydrol., 330, 543-563.

Pinder, G.F., Jones, J.F., 1969. Determination of the groundwater component of peak discharge from the chemistry of total runoff water. Water Resour. Res., 5, 438-455.

Sanda, M., Cislerova, M., 2009. Transforming hydrographs in the hillslope subsurface. J. Hydrol. Hydromech., 57, 264 275.

Sanda, M., Kulasova, A., Cislerova, M., 2009. Hydrological processes in the subsurface investigated by water isotopes and silica. Soil \& Water Res., 4, 83-92.

Sanda, M., Vitvar, T., Kulasova, A., Jankovec, J., Cislerova, M., 2014. Run-off formation in a humid, temperate headwater catchment using a combined hydrological, hydrochemical and isotopic approach (Jizera Mountains, Czech Republic). Hydrol. Process., 28, 3217-3229. DOI: 10.1002/hyp.9847.

Stockinger, M.P., Bogena, H.R., Lucke, A., Diekkruger, B., Weiler, M., Vereecken, H., 2014. Seasonal soil moisture patterns: Controlling transit time distributions in a forested headwater catchment. Water Resour. Res., 50, 5270-5289.

Tesar, M., Sir, M., Prazak, J., Lichner, L., 2004. Instability driven flow and runoff formation in a small catchment. Geologica Acta, 2, 147-156.

Tetzlaff, D., Seibert, J., Soulsby, C., 2009. Inter-catchment comparison to assess the influence of topography and soils on catchment transit times in a geomorphic province; the Cairngorm mountains, Scotland. Hydrol. Processes, 23, 1874-1886.

Tromp-van Meerveld, H.J., McDonnell, J.J., 2006. Threshold relations in subsurface stormflow: 2. The fill and spill hypothesis. Water Resour. Res., 42, W02411. DOI: 10.1029/2004WR003800.

Urban, L., 2014. Evaluation of runoff conditions in Liz catchment using stable isotopes. Bachelor Thesis. CTU in Prague, Prague, Czech Republic.

Vogel, T., Sanda, M., Dusek, J., Dohnal, M., Votrubova, J., 2010. Using oxygen-18 to study the role of preferential flow in the formation of hillslope runoff. Vadose Zone J., 9, 252259. DOI: $10.2136 /$ vzj2009.0066.

Wenninger, J., Uhlenbrook, S., Lorentz, S., Leibundgut, Ch., 2008. Identification of runoff generation processes using combined hydrometric, tracer and geophysical methods in a headwater catchment in South Africa. Hydrol. Sci. J., 53, 65-80. DOI: 10.1623/hysj.53.1.65.

Zuecco, G., Penna, D., Borga, M., van Meerveld, H.J., 2015. A versatile index to characterize hysteresis between hydrological variables at the runoff event timescale. Hydrol. Process. DOI: $10.1002 /$ hyp. 10681 .

Received 8 April 2016 Accepted 5 September 2016 